\title{
Pertolongan Pertama Kecelakaan Di Keluarga
}

\author{
Hafni Zuchra Noor*, Denny Anggoro Prakoso* \\ *Program Studi Pendidikan Dokter, Fakultas Kedokteran dan IImu Kesehatan, Universitas Muhammadiyah Yogyakarta \\ Jl. Bawijaya, Tamantirto, Kasihan, Bantul,Yogyakarta \\ Email: hafni.z.n@gmail.com \\ DOI: $10.18196 / p p m .36 .325$
}

\begin{abstract}
ABSTRAK
Cedera karena kecelakaan, yang bisa meliputi apa saja mulai dari jatuh dan terbakar hingga luka, sering terjadi di rumah. Tingkat pengetahuan tentang kecelakaan yang dapat terjadi di keluarga, dapat memengaruhi sikap dan tindakan pertolongan pertama di rumah. Oleh karena itu, edukasi tentang pertolongan pertama kecelakaan di kelvarga sangatlah penting, tidak hanya kepada ibu saja, tetapi kepada seluruh anggota keluarga. Diharapkan dengan pemberian bekal pengetahuan tentang pertolongan pertama kecelakaan di keluarga dapat menurunkan tingkat kesalahan dan keparahan dari kejadian kecelakaan di rumah dan juga dapat mencegah terjadinya hal tersebut. Pengabdian dilakukan dengan cara virtual melalui whatsapp group (WAG) dan memberikan paparan edukasi melalui video edukasi di youtube. Tiga puluh delapan peserta mengikuti edukasi dengan baik dan peserta diberikan sepuluh soal sebelum dan sesudah edukasi. Hasil kegiatan berupa meningkatnya kepahaman peserta pengabdian terhadap pertolongan pertama kecelakaan di keluarga atau rumah tangga.
\end{abstract}

Kata kunci: kecelakaan, keluarga, rumah tangga, pertolongan pertama

\section{Pendahuluan}

Cedera karena kecelakaan, yang bisa meliputi apa saja mulai dari jatuh dan terbakar hingga luka, sering terjadi di rumah. Faktanya, ini adalah lokasi paling umum kedua dari cedera fatal yang tidak disengaja.1 Secara global, kecelakaan di rumah merupakan penyebab utama kecacatan yang dapat dicegah dan kematian di kalangan anak-anak dan remaja.2 Kecelakaan di rumah dikategorikan sebagai jatuh, terpotong, terbakar, tenggelam, aspirasi benda asing, sengatan listrik, dan karbon monoksida dan jenis keracunan lainnya.3 Terdapat suatu penelitian yang menilai pengetahuan pertolongan pertama pada ibu rumah tangga, menentukan sikap dan perilaku ibu rumah tangga dalam pencegahan kecelakaan rumah tangga dan memeriksa faktor - faktor yang berkaitan dengan tingkat pengetahuan pertolongan pertama, sikap dan perilaku dalam pencegahan kecelakaan rumah tangga dengan hasil penelitian skor pengetahuan pertolongan pertama meningkat sesuai dengan tingginya level pendidikan populasi studi, skor pengetahuan pertolongan pertama wanita yang bekerja lebih tinggi daripada wanita yang tidak bekerja, skor sikap dan perilaku populasi penelitian meningkat dengan meningkatnya tingkat pendidikan dan status ekonomi dan menurun dengan bertambahnya usia. Sikap preventif dan skor perilaku wanita yang belum mengalami kecelakaan di rumah lebih tinggi.4

Anak-anak di bawah usia lima tahun berisiko tinggi mengalami banyak kecelakaan seperti luka bakar dan jatuh.5 Penelitian di empat negara berpenghasilan rendah mengungkapkan bahwa $65 \%$ luka bakar pada masa kanak-kanak terjadi di dalam dan sekitar lingkungan rumah. Laporan Organisasi Kesehatan Dunia (WHO) menyatakan bahwa cedera pada anak di bawah usia lima tahun meningkat dengan bertambahnya usia dari satu menjadi lima tahun.6 Lebih dari sepertiga lansia menderita jatuh setiap tahun, dan 20\% hingga 30\% mengalami cedera sedang hingga parah seperti pinggul patah tulang dan cedera kepala yang mengurangi mobilitas dan kemandirian mereka.7

Di Indonesia, sebagian masyarakat memiliki kebiasaan mencari pengobatan sesuai dengan mitos-mitos yang ada, Fenomena yang sering terjadi di masyarakat dalam menangani luka bakar yaitu menggunakan telur, pasta gigi, mentega, minyak kelapa, madu, dan kentang dalam 
penanganan awal sebelum ke tempat pelayanan kesehatan. 8 Hal tersebut dapat memperburuk kondisi luka dan menimbulkan infeksi.

Pengabdian ini bertujuan untuk memulai edukasi tentang pertolongan pertama kecelakaan di keluarga. Diharapkan dengan pemberian bekal pengetahuan tentang pertolongan pertama kecelakaan dikeluarga dapat menurunkan tingkat kesalahan dan keparahan dari kejadian kecelakaan di rumah dan juga dapat mencegah terjadinya hal tersebut.

\section{Metode Pelaksanaan}

Pengabdian kami laksanakan secara online karena saat ini pandemi COVID-19 masih belum mereda. Kami melakukan pengabdian kepada ibu-ibu Yayasan Sekolah Ibu "Bunda Sholihah" Yogyakarta yang beralamat di Kembaran, Tamantirto, Kasihan, Bantul. Kami memilih yayasan tersebut karena sebagian besar ibu-ibu di sana merupakan ibu rumah tangga yang masih banyak mengaplikasikan penanganan cedera berdasarkan mitos yang ada. Pengabdian dilaksanakan melalui whatsapp group dengan metode yang digunakan dalam pelaksanaan kegiatan ini yaitu:

1. Melakukan pretest untuk mengetahui sejauh mana pemahaman pentingnya pengetahuan, pertolongan pertama, dan pencegahan kecelakaan di keluarga melalui pengisian soal pilihan ganda sebanyak 10 buah melalui google form sebelum pemberian video edukasi.

2. Memberikan video edukasi sebagai sarana pembagian materi yang terbagi menjadi empat subtema yaitu jatuh, terbakar, tersetrum, dan tersedak.

3. Setelah semua peserta melihat video, dilanjutkan dengan diskusi tanya jawab.

4. Lalu dilanjutkan dengan posttest untuk megetahui sejauh mana pemahaman pentingnya pengetahuan pertolongan pertama, dan pencegahan kecelakaan di keluarga melalui pengisian soal pilihan berganda sebanyak 10 buah melalui google form setelah pemberian video edukasi dan diskusi.

\section{Hasil dan Pembahasan}

1. Hasil

Sebanyak tiga puluh delapan peserta mengikuti kegiatan pengabdian ini. Seluruh peserta antusias selama mengikuti kegiatan pengabdian dan aktif saat sesi diskusi. Profil responden dalam penelitian ini meliputi usia dan pekerjaan. Adapun hasilnya adalah sebagai berikut:

Tabel 1. Profil responden

\begin{tabular}{clcc}
\hline No & Profil & Frekuensi & $\%$ \\
\hline 1. & Umur & & \\
\hline & $\leq 30$ tahun & 16 & 42,1 \\
\hline $31-40$ tahun & 9 & 23,7 \\
\hline & $>41$ tahun & 13 & 34,2 \\
\hline & Jumlah & 38 & 100 \\
\hline $2 . \quad$ Pekerjaan & & 71,0 \\
\hline & Ibu Rumah Tangga & 27 & 7,9 \\
\hline & Wirausaha & 3 & 7,9 \\
\hline & Wirasawsta & 3 & 2,7 \\
\hline & Guru & 1 & 10,5 \\
\hline & Buruh & 4 & 100 \\
\hline
\end{tabular}

Tabel di atas menunjukkan bahwa sebagian besar peserta berumur $\leq 30$ tahun, yaitu 16 responden (42,1\%), dan paling sedikit berumur 31 - 41 tahun, yaitu 9 peserta $(23,7 \%)$. Berdasarkan 
pekerjaan, sebagian besar adalah ibu rumah tangga yaitu 27 responden (71,0\%), dan paling sedikit adalah guru, yaitu 1 peserta $(2,7 \%)$.

Pelaksanaan pretest dan posttest merupakan salah satu cara untuk mengevaluasi keefektifan kegiatan pengabdian ini. Berikut disajikan tabel hasil pretest dan postest materi pertolongan pertama kecelakaan di keluarga.

Tabel 2. Hasil Pretest dan Posttest

\begin{tabular}{cccccc}
\hline Rata - rata & Pretest & \multicolumn{3}{c}{ Posttest } \\
& $\begin{array}{c}\text { Nilai } \\
\text { terendah }\end{array}$ & $\begin{array}{c}\text { Nilai } \\
\text { tertinggi }\end{array}$ & Rata - rata & $\begin{array}{c}\text { Nilai } \\
\text { terendah }\end{array}$ & $\begin{array}{c}\text { Nilai } \\
\text { tertinggi }\end{array}$ \\
\hline 70 & 50 & 100 & 87,4 & 50 & 100 \\
\hline \multicolumn{7}{c}{ Tabel 3. Deskripsi Hasil Pretest dan Posttest } \\
\hline Nilai & Pretest & \multicolumn{4}{c}{ Posttest } \\
\hline $50-70$ & 25 & 65.8 & $50-70$ & 5 & 13.1 \\
\hline $80-100$ & 13 & 34.2 & $80-100$ & 33 & 86.9 \\
\hline Total & 38 & 100 & Total & 38 & 100 \\
\hline
\end{tabular}

Nilai pretest dan posttest peserta pengabdian ditunjukkan pada tabel 2 dan 3 . Rerata nilai pretest dan posttest adalah 70 dan 87,4 dengan nilai terendah dan tertingginya sama yaitu 50 dan 100 . Jumlah peserta pretest dengan rentang nilai 50 - 70 sebanyak 25 orang $(65,8 \%)$ sedangkan posttest sebanyak 5 orang $(13,1 \%)$. Dan jumlah peserta pretest dengan rentang nilai $80-100$ sebanyak 13 orang $(34,2 \%)$ sedangkan posttest sebanyak 33 orang $(86,9 \%)$.

\section{Pembahasan}

Kecelakaan adalah kejadian yang tidak direncanakan, tidak terduga, dan dapat dicegah. Kecelakaan dapat terjadi tiba-tiba dan mengakibatkan cedera serta kerusakan. ${ }^{3}$ Para lansia lebih sering mengalami kecelakaan di rumah daripada kelompok usia lainnya karena mereka menghabiskan sebagian besar waktu mereka di rumah. Kecelakaan rumah didefinisikan sebagai kecelakaan yang terjadi di dalam atau di sekitar (taman atau garasi) rumah. ${ }^{9}$ Terdapat suatu penelitian yang menunjukkan bahwa terdapat prevalensi rumah sakit yang tinggi dari kecelakaan rumah yang tidak disengaja yaitu 77 dari 1.000 anak yang datang selama periode enam bulan. ${ }^{10}$

Peserta yang mengikuti kegiatan ini sebanyak tiga puluh delapan peserta dan paling banyak peserta berumur $\leq 30$ tahun, yaitu 16 responden $(42,1 \%)$. Usia ibu merupakan salah satu variabel yang relevan dalam penentuan tampilan pengetahuan dalam kasus penyebab dan pencegahan kecelakaan rumah seperti yang diamati Ibrahim (2004) bahwa begitu banyak kecelakaan yang bisa ditangani jika orang tua dengan anak tahu apa yang harus dilakukan segera setelah terjadi. ${ }^{11}$

Berdasarkan informasi data pada tabel 2 dan 3 dapat diketahui bahwa terjadi peningkatan nilai pada posttest setelah dilakukan edukasi materi melalui pembagian video dan link youtube, sehingga dapat dikatakan bahwa pemahaman pentingnya pengetahuan, pertolongan pertama, dan pencegahan kecelakaan di keluarga yaitu dengan subtema jatuh, terbakar, tersetrum, dan tersedak para peserta meningkat. Pada penelitian lain menunjukkan bahwa penyuluhan efektif dalam meningkatakan pengetahuan, meningkatkan menejemen diri, serta membiasakan pengamanan yang tepat dapat penanganan kecelakaan kerja dari rumah tangga. ${ }^{12}$ Terlaksananya kegiatan ini dan adanya peningkatan pengetahuan dari peserta, maka besar harapan kami agar peserta mampu mencegah, dan memberikan pertolongan pertama apabila terjadi cedera pada anggota keluarga karena 
pengetahuan dan perilaku dari manusia sendiri sangat memengaruhi kecepatan dan ketepatan dalam melakukan pertolongan pertama pada korban. ${ }^{13}$

\section{Simpulan}

Kegiatan pengabdian kepada masyarakat dilakukan dengan metode pemberian materi penyuluhan melalui video atau link youtube. Pendampingan, diskusi, dan evaluasi telah dilakukan dengan hasil menunjukkan peningkatan pemahaman pengetahuan, pertolongan pertama dan pencegahan kecelakaan di keluarga.

\section{Ucapan Terima Kasih}

Ucapan terima kasih kami tujukan terutama kepada pemberi dana LP3M UMY. Ucapan terima kasih juga kami tujukan kepada ibu-ibu Yayasan Sekolah Ibu "Bunda Sholihah" Yogyakarta yang telah berpartisipasi dalam kegiatan pengabdian ini, serta semua kerabat kerja yang turut membantu dalam terlaksananya program pengabdian ini.

\section{Daftar Pustaka}

Peden M, Oyegbite K, Ozanne-Smith J. World report on child injury prevention. Geneva: WHO; 2008, Vol. 1-22, pp. 79-115.

UNICEF. The state of the world's children. New York: UNICEF; 2009.

Aydın, N. (2016). Home accidents. Türkiye Klinikleri Journal of Public Health-Special Topics, $21,17-22$

Ersin U, Fadimana A, Mustafa Ö, Ahmet, Nesimi K. The attitudes and behaviors of housewives in the prevention of domestic accidents and their first aid knowledge levels. Turkish Journal of Trauma \& Emergency Surgery. Ulus Travma Acil Cerrahi Derg 2008;14(1):46-52

Hyder AA, Sugerman DE, Puvanachandra P, Razzak J, El-Sayed H, Isaza A, et al. Global childhood unintentional injury surveillance in four cities in developing countries: a pilot study. Bull World Health Organ. 2009;87(5):345-52.

Peden M, Oyegbite K, Ozanne-Smith J, Hyder AA, Branche C, Rahman AKM F, Rivara F, Bartolomeos K, editors. World report on child injury prevention. Geneva: WHO; 2008.

Susilowardani D, Istiono W, Pramantara DP. Adaptation of home falls and accidents screening tool (HOME FAST) as a fall risk screening tool for the elderly in first level health facilities at Purworejo Regency. Rev Prim Care Prac and Educ. 2020; 3(2): 6-13

Kattanetal. Current knowledge of burn injury first aidpractices and applied traditional remedies:a nationwide survey Burns\&Trauma (2016) 4:37

Yapici et al. Determination of the Home Accident Frequency and Related Factors Among the People Older than 65 Years Old Living in Mersin City Center, Turkey. SAGE Open, AprilJune 2019: $1-11$

Alya AR, Huda AA, Mahmood AB, Salim AR. Home Accidents among Children: A Retrospective Study at a Tertiary Care Center in Oman. Oman medical Journal [2020], vol. 35, no. 1: e85

Ibrahim A, (1994). Assessment of knowledge, attitude and practice of mother's attending Cairo University

Notosiswoyo,.2008. Uji Coba Modul Penyuluhan Tentang Pencegahan Kecelakaan Rumah Tangga Pada Penduduk Pra Usia Lanjut di Kabupaten Sleman. Ejournal.litbang.depkes.go.id vol 18. no.1

Sudiharto \& Sartono. (2011). Basic Trauma Cardiac Life Support. Jakarta: CV Sagung Seto 